\title{
Analysis of Causes and Effects of Applying IAS And IFRS in Case of Mergers and Acquisitions of Banks in the Federation of Bosnia and Herzegovina
}

\author{
Meliha Bašić*, Haris Jahić*, Lejla Jahić*
}

\begin{abstract}
:
One of the effect of the "stabilization and accession" process, i.e. of fulfilling requirements for entry of the state of Bosnia and Herzegovina into the European Union, over the past few years, has been the privatization and concentration of banks' capital, primarily through the process of their mergers. 1 The paper is primarily aimed at analyzing the way, causes and effects of applying IAS and IFRS in mergers and acquisitions of banks in the Federation of Bosnia and Herzegovina. The presented analysis revealed the discrepancy between regulations by the Banking Agency of Federation Bosnia and Herzegovina, as the supervisory body for banking in this part of $\mathrm{BH}$ and IAS and IFRS, particularly with respect to the framework for financial reporting for banks, a lack of detailed disclosure prescribed by IAS and IFRS, as well as of instructions and methodology related to the processes that must be conducted. It directly resulted in unrealistic, unbjective and, naturally, insufficiently comprehensible, and insufficiently controllable and comparable financial statements by given banks, before and after mergers and acquisitions. In the same time, it made it more difficult to do business, conduct internal and external control and auditing, particularly by a regulatory body, and resulted in a series of objections by foreign controllers (IMF, IBRD). The conducted research points to problems present in practice with respect to mergers and acquisitions of banks in the Federation B-H, and provides guidelines for their possible solution.
\end{abstract}

Key words: mergers, acquisitions, bank, IAS, IFRS, European Union

\section{Introduction}

The two most common models of bank association in $\mathrm{B} \& \mathrm{H}$ have been the model of bank mergers and the model of bank acquisitions respectively. Law on

${ }^{1}$ In 2010, the number of banks in the Federation of Bosnia and Herzegovina (20 banks) was by 18 banks smaller compared to 2000 (38 banks), which is due both to globalization and to the merger and acquisition processes.

*School of Economics and Business, University of Sarajevo, Bosnia and Herzegovina 
Banking distinguished between these two types of association. The difference is reflected in that the model of acquisition does not imply establishment of a new bank; rather, the acquired bank is "immersed" into an existing bank. Model of two or more banks merger implies the establishment of a new bank, while the banks that participate in the merger process cease to exist.

The given processes can be viewed from a few microeconomic and macroeconomic aspects. Within the microeconomic aspect, for our research needs, the paper will above all deal with the accounting aspect of bank mergers and acquisitions in the FB\&H. A special emphasis will also be placed on the accounting models and problems in applying IFRS and IAS, both the existing ones and the latest ones, published by the Committee for publishing international standards of the models of discussed combinations. ${ }^{2}$

\section{Subject and Goal of the Research}

Article 26 of the Law on Banking ${ }^{3}$ includes provisions pertaining to bank mergers and acquisitions. Since it is evident that the largest part of the $\mathrm{BH}$ banking system is foreign-owned, a problem of the discrepancy between legal regulations of $\mathrm{FB} \& \mathrm{H}$ and $\mathrm{EU}$ regulations arises. The discrepancy primarily pertains to IAS and IFRS.

Consequently, we can define the subject of the research.

Do users of banks' financial statements have access to all the prescribed information on the impact of mergers and acquisitions on the bank's financial position?

Have the business and accounting policies of banks being merged and acquired been harmonized?

In the merger and acquisition processes, did banks use certain models pertaining to the necessary accounting procedures of these processes in practice?

The goal of the research conducted was to identify regulations that define bank accounting and financial reporting framework, and to establish deviations compared to IAS and IFRS, in case of FB\&H banks' mergers and acquisitions in the banking system of Federation Bosnia and Herzegovina.

The research we conducted in case of identification of business mergers and acquisitions in the Federation B\&H revealed that, in the period 2000-2010 nine cases of bank acquisitions and three cases of bank mergers were identified. The

2 Međunarodni računovodstveni standardi i Međunarodni standardi finansijskog izvještavanja,

Udruženje/udruga računovođa i revizora FBiH, Sarajevo, 2010. http://www.srrfbih.org/bo/msfi_mrs.asp

${ }^{3}$ Zakon o bankama, Službene novine FBiH, issues 39/98,32/00, 48/01, 27/02, 41/02, 58/02, $13 / 03,19 / 03$ and 28/03. 
research presented below shows that accounting problems with the application of IAS and IFRS were and still remain present.

\section{Research Hypotheses}

Having in mind the above described, we have defined research hypotheses:

H0: In FB\&H, there is insufficiency, discrepancy, and lack of updated regulations, misunderstanding, insufficient and inadequate education, and insufficient and inadequate control and auditing, both external and internal, for bank mergers and acquisitions, particularly in their accounting aspect. Banks that are merged and acquired in $\mathrm{B} \& \mathrm{H}$ do not disclose all the information that allows financial statement users to assess the nature and financial effects of business mergers and acquisitions.

$\mathrm{H1}$ : In $\mathrm{FB} \& \mathrm{H}$, there is an obvious discrepancy between legal regulations of FB\&H compared to those of the EU pertaining to the accounting aspect of mergers and acquisitions.

H2: Banking Agency of the Federation of $\mathrm{B} \& \mathrm{H}$ does not require banks to disclose detailed information provided for by IAS and IFRS, nor gives detailed instructions and methodology of the process that has to be carried out, so that the given process could be completed in such a way that it results in a realistic, objective and comprehensible financial statement before and after merger and acquisition, as well as an established accounting system that can be adequately controlled and audited internally and externally, particularly by a regulatory body.

\section{Research Methodology}

In order to accept or reject the sub-hypotheses and main hypothesis set in the paper, we conducted research pertaining to causes and effects of the application of IAS and IFRS in the case of bank mergers and acquisitions in the banking system of Federation B\&H.

The research was conducted by means of survey questionnaire. The questionnaire used in the research was divided into two sections. The first section dealt with general questions, while the second section of the survey questionnaire consisted of 16 questions related to our research hypotheses. The first, introductory section of the survey questionnaire was supposed to provide the following information about banks: bank name, bank seat, bank ownership, structure of bank capital (\%), number of shareholders, number of employees as of $31 / 12 / 2010$, locations of branches opened in $\mathrm{B} \& \mathrm{H}$, whether the banks 
underwent merger or acquisition with (an)other bank(s), bank name in case of acquisition or merger with another bank, title of bank's employee who filled in the questionnaire.

The second section of survey questionnaire was conceived in the way which required respondents to provide responses to asked questions/statements by rating their agreement with the statements using ratings from one to five. The questionnaire also included some open-end questions where respondents could freely express their attitudes and views related to our research. Ratings from one to five signified:

1 - strongly disagree

2 - disagree

3 - somewhat agree

4 - agree

5 - strongly agree.

The survey was not anonymous, although banks were asked to point out if they did not want certain data to be disclosed.

\subsection{Description of sample and research method}

The questionnaire was designed in such a way that all the questions were related to the main hypothesis and sub-hypotheses. We conducted the research into the accounting aspect of bank mergers and acquisitions in FB\&H in the Federation of Bosnia and Herzegovina in the period September-October 2010, on the sample of 20 banks that were licensed by the Banking Agency of FB\&H in the period. Data were collected by distributing the e-mail survey and mail survey, and respondents were defined as financial experts or competent individuals familiar with the area of accounting.

The survey questionnaire was filled in and returned by 16 banks, which makes up a return rate of $80 \%$. With respect to the capital category, the number of employees and the number of banks that underwent merger or acquisition, we will present the following table:

Based on the data shown in Table 1, we consider the sample to be significant for the following reasons:

- The total capital of banks ${ }^{4}$ in FB\&H as of 31/12/2010 amounted to $2,061,824,000 \mathrm{KM}$ a day. The total capital of banks that filled in the questionnaire amount to $1,747,426,000 \mathrm{KM}$, which makes up a share of $84.75 \%$ in the total capital of FB\&H banks, which is shown by the following figure:

${ }^{4}$ Banks that held the working license issued by the Banking Agency of FB\&H as of $31 / 12 / 2010$ 
Table 1. Capital - the number of employees and the number of banks that underwent a merger or acquisition proves in FB\&H as of $31 / 12 / 2010^{5}$

\begin{tabular}{|c|c|c|c|c|}
\hline $\begin{array}{c}\mathrm{N} \\
\text { O. }\end{array}$ & $\begin{array}{c}\text { Panks in } \\
\text { FB\&H (20 } \\
\text { banks })\end{array}$ & $\begin{array}{c}\text { Banks that } \\
\text { filled in } \\
\text { questionnaire } \\
(16 \text { banks })\end{array}$ & $\begin{array}{c}\text { Banks that did } \\
\text { not fill in the } \\
\text { questionnaire } \\
\text { banks })\end{array}$ \\
\hline 1. & Capital as of $31 / 12 / 2010$. & 2.061 .824 .000 & 1.747 .426 .00 & 314.398 .000 \\
0 & 7.129 & 259 \\
\hline 2. & $\begin{array}{l}\text { Number of employees as of } \\
31 / 12 / 2010 .\end{array}$ & 7.338 & 12 & 0 \\
\hline 3. & $\begin{array}{l}\text { Number of banks that } \\
\text { underwent a merger or } \\
\text { acquisition process }\end{array}$ & 12 & & \\
\hline
\end{tabular}

\section{Capital as of 31/12/2010.}

314.398 .000
$15,25 \%$
Capital of FB\&H banks that did not fill

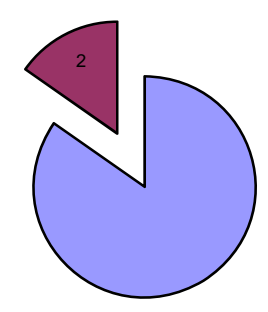

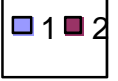

1

1.747.426.000

$84,75 \%$

Capital of FB\&H banks that filled in the questionnaire

Figure 1. Capital of banks in FB\&H as of 31/12/2010

Source: authors' research

As of $31 / / 12 / 2010, F B \& H$ banks had a total of 7,388 employees. The total number of employees in the $16 \mathrm{FB} \& \mathrm{H}$ banks that filled in the questionnaire was 7,129 , which makes up a 96.94 share in the total number of employees in the FB\&H banking sector. It is shown by the following figure:

\footnotetext{
${ }^{5}$ Data taken from the website http://www.fba.ba/index.php?page=37 (Publications-banks)
} 
Figure 2. The number of employees in FB\&H banks as of 31/12/2010

Number of employees as of 31/12/2010.

259

$4 \%$

Number of employees in banks that did

not fill in the questionnaire

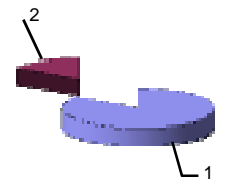

Number of employees in banks that filled in the questionnaire

Source: Authors' research

- Out of 20 banks that were granted a working license by the Banking Agency of FB\&H, the sample of 16 banks that filled in the questionnaire includes all the banks that underwent a case of merger or acquisition, which is shown in the following figure:

Figure 3. The number of banks in FB\& ${ }^{2} H$ that have undergone a merger or acquisition process

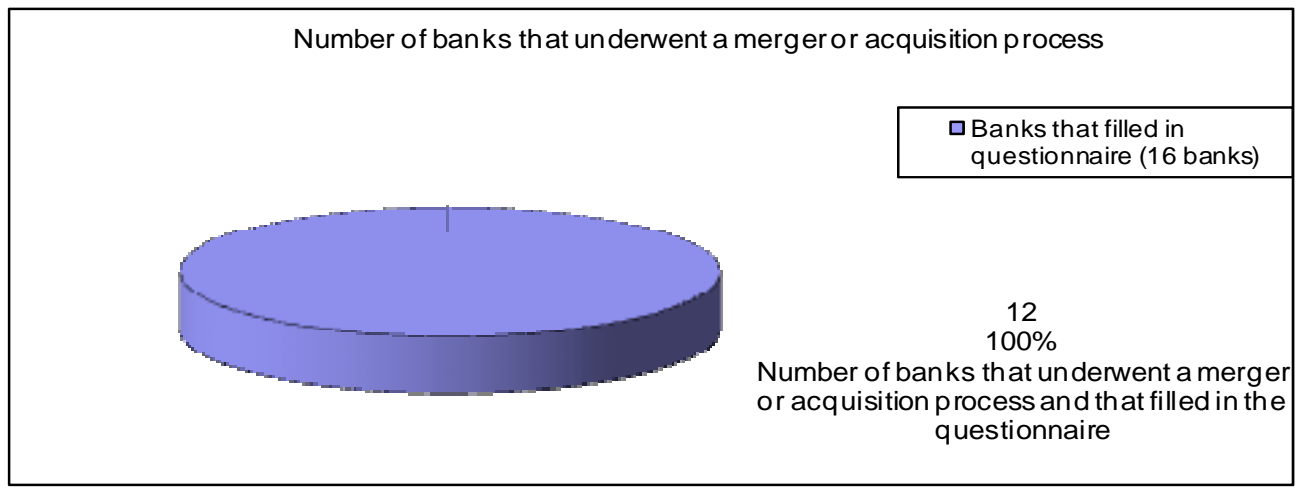

Source: Authors' research

Based on the above described, we believe that the conclusions of the presented analysis pertaining to the accounting aspect of bank mergers and acquisitions in 
FB\&H will provide a clearer picture of causes and effects of applying IAS/IFRS in case of bank mergers and acquisitions in $\mathrm{FB} \& \mathrm{H}$.

Collection and analysis of empirical data used qualitative and quantitative research methods: sampling methods, quantitative empirical research methods, survey method on the sample of all banks operating in the Federation of $B \& H$, interview method, graphic and numerical methods, and procedures of statistical hypothesis testing using the Student's t-test. ${ }^{6}$ For each hypothesis (main and subhypotheses), the standard statistical procedure will be used to calculate the basic descriptive variable parameters, as follows:

- $\operatorname{arithmetic~mean~}(\bar{X})$,

- standard deviation (s),

- minimum results,

- maximum results.

Mathematical formula for calculating standard deviations ${ }^{7}$ is the following:

$$
\sigma=\sqrt{\frac{1}{N} \sum_{i=1}^{N}\left(x_{i}-\bar{x}\right)^{2}}
$$

Responses to the questions asked in the survey questionnaire are presented in the following table:

\footnotetext{
${ }^{6}$ When a sample (n) is smaller than 30 , the Student's distribution table is used.

${ }^{7}$ Standards deviation signifies the measure of data deviation in the sample. It is explained as average deviation from the average, in the absolute amount.
} 
Table 2. Responses to questions asked in the survey questionnaire related to the hypotheses of research into the accounting aspect of bank mergers and acquisitions in $\mathrm{FB} \& \mathrm{H}$

\begin{tabular}{|c|c|c|c|c|c|c|c|}
\hline \multirow{3}{*}{$\begin{array}{c}\text { Quetsions/ } \\
\text { Rating }\end{array}$} & Strongly & Disagree & Somewh & Agree & Strongly & \multirow{3}{*}{ 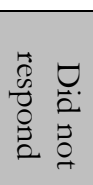 } & \multirow{3}{*}{ 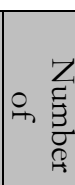 } \\
\hline & & & & & & & \\
\hline & 1 & 2 & 3 & 4 & 5 & & \\
\hline 1. & 10 & 0 & 0 & 0 & 6 & 0 & 16 \\
\hline 2. & 0 & 4 & 8 & 4 & 0 & 0 & 16 \\
\hline 3. & 0 & 3 & 3 & 5 & 5 & 0 & 16 \\
\hline 4. & 0 & 4 & 2 & 5 & 5 & 0 & 16 \\
\hline 5. & 0 & 2 & 3 & 6 & 5 & 0 & 16 \\
\hline 6. & 0 & 3 & 3 & 6 & 4 & 0 & 16 \\
\hline 7. & 0 & 4 & 3 & 4 & 5 & 0 & 16 \\
\hline 8. & 0 & 1 & 2 & 7 & 5 & 1 & 16 \\
\hline 9. & 0 & 2 & 7 & 1 & 1 & 5 & 16 \\
\hline 10. & 0 & 0 & 5 & 6 & 5 & 0 & 16 \\
\hline 11. & 0 & 0 & 6 & 4 & 3 & 3 & 16 \\
\hline 12. & 0 & 0 & 2 & 4 & 2 & 9 & 16 \\
\hline 13. & 0 & 0 & 2 & 11 & 3 & 0 & 16 \\
\hline
\end{tabular}

Source: Authors' research

\section{Research Results}

Based on the results of the survey presented in Table 2 , it is necessary to establish the confidence interval for the arithmetic mean of evaluated responses for our measurement pertaining to the accounting aspect of bank mergers and acquisitions in $\mathrm{FB} \& \mathrm{H}$ (as the population with an unknown variance), in order to be able to confirm or reject the set hypotheses (main hypothesis and subhypotheses) related to the research goal. As we mentioned, we will use Student's t-test.

In the following section, for each set hypothesis (main and sub-hypotheses) we will calculate arithmetic mean, standard deviation, minimum and maximum results and, based on the calculated data and using Student's t-test, determine the interval, in order to be able to accept or reject the set hypotheses. 
Table 3. Arithmetic mean, standard deviation, minimum and maximum results, confidence interval for two-tailed and one-tailed critical t-test value

\begin{tabular}{|c|c|c|c|c|c|}
\hline $\begin{array}{l}\text { Hypothesi } \\
\text { s }\end{array}$ & $\begin{array}{c}\mathrm{Nr} \text { of } \\
\text { responses }\end{array}$ & $\begin{array}{l}\text { Min } \\
1\end{array}$ & $\begin{array}{l}\text { Max } \\
5\end{array}$ & Arithmetic mean & $\begin{array}{l}\text { Standard } \\
\text { deviation }\end{array}$ \\
\hline Ho & 16 & 1 & 5 & 3,55 & 2,21 \\
\hline \multicolumn{6}{|c|}{ Two-tailed critical t-value } \\
\hline $\begin{array}{l}\text { Significan } \\
\text { ce level }\end{array}$ & df & \multicolumn{2}{|c|}{ Value } & \multicolumn{2}{|l|}{ Interval } \\
\hline $95 \%$ & 15 & \multicolumn{2}{|c|}{7,260} & $\left(\bar{X}-7,260 \cdot \frac{s}{\sqrt{15}}, \bar{X}+7,260 \cdot \frac{s}{\sqrt{15}}\right.$ & $=(-2,03,+9,13)$ \\
\hline \multicolumn{6}{|c|}{ One-tailed critical t-value } \\
\hline $\begin{array}{l}\text { Significan } \\
\text { ce level }\end{array}$ & $\mathrm{df}$ & \multicolumn{2}{|c|}{ Value } & \multicolumn{2}{|l|}{ Interval } \\
\hline $95 \%$ & .15 & \multicolumn{2}{|c|}{1,753} & \multicolumn{2}{|c|}{$\bar{X}-1,753 \circ \frac{s}{\sqrt{15}}=2,55 \prec 3,55$} \\
\hline Hypothesis & $\begin{array}{l}\mathrm{Nr} \text { of } \\
\text { responses }\end{array}$ & $\begin{array}{l}\text { Min } \\
1\end{array}$ & $\begin{array}{l}\text { Max } \\
5\end{array}$ & Arithmetic mean & $\begin{array}{l}\text { Standard } \\
\text { deviation }\end{array}$ \\
\hline H1 & 7 & 3 & 5 & 4,57 & 1,30 \\
\hline \multicolumn{6}{|c|}{ Two-tailed critical t-value } \\
\hline Sig. level & $\mathrm{df}$ & \multicolumn{2}{|c|}{ Value } & \multicolumn{2}{|l|}{ Interval } \\
\hline $95 \%$ & 15 & \multicolumn{2}{|c|}{7,260} & $\left(\bar{X}-7,260 \cdot \frac{s}{\sqrt{15}}, \bar{X}+7,260 \cdot \frac{s}{\sqrt{15}}\right.$ & $=(+2,18,+6,96)$ \\
\hline \multicolumn{6}{|c|}{ One-tailed critical t-value } \\
\hline Sig. level & $\mathrm{df}$ & \multicolumn{2}{|c|}{ Value } & \multicolumn{2}{|l|}{ Interval } \\
\hline $95 \%$ & 15 & \multicolumn{2}{|c|}{1,753} & \multicolumn{2}{|c|}{$\bar{X}-1,753 \circ \frac{s}{\sqrt{15}}=4,00<4,75$} \\
\hline Hypothesis & $\begin{array}{l}\mathrm{Nr} . \quad \text { of } \\
\text { responses }\end{array}$ & $\begin{array}{l}\text { Min } \\
1\end{array}$ & $\begin{array}{l}\text { Max } \\
5\end{array}$ & Arithmetic mean & $\begin{array}{l}\text { Standard } \\
\text { deviation }\end{array}$ \\
\hline H2 & 16 & 3 & 5 & 4,06 & 0,90 \\
\hline \multicolumn{6}{|c|}{ Two-tailed critical t-value } \\
\hline Sig. level & $\mathrm{df}$ & \multicolumn{2}{|c|}{ Value } & \multicolumn{2}{|l|}{ Interval } \\
\hline $95 \%$ & 15 & \multicolumn{2}{|c|}{7,260} & $\left(\bar{X}-7,260 \cdot \frac{s}{\sqrt{15}}, \bar{X}+7,260 \cdot \frac{s}{\sqrt{15}}\right.$ & $=(+2,39,+5,73)$ \\
\hline \multicolumn{6}{|c|}{ One-tailed critical t-value } \\
\hline Sig. level & $\mathrm{df}$ & \multicolumn{2}{|c|}{ Value } & \multicolumn{2}{|l|}{ Interval } \\
\hline $95 \%$ & 15 & \multicolumn{2}{|c|}{1,753} & \multicolumn{2}{|c|}{$\bar{X}-1,753 \circ \frac{s}{\sqrt{15}}=3,65<4,06$} \\
\hline
\end{tabular}

Source: Authors' research 
Based on the data collected using the survey and the calculated data presented in Table 3, we determined the confidence interval for the arithmetic mean of observed population (related to responses to questions pertaining to the main hypothesis and sub-hypotheses). Based on the significance of $95 \%$, we determined the two-tailed and one-tailed critical t-value. The two-tailed critical tvalue for 15 degrees of freedom ( $n-1=16-1=15)$, equals 7.260 . Therefore, we can claim with the $95 \%$ certainty that the arithmetic mean of main hypothesis $(\mathrm{H})$ ) and sub-hypotheses (H1) and (H2) belongs to the set interval in Table 2. Viewing the calculated data in Table 2 for the main hypothesis ( $\mathrm{H} 0)$, we can see that the arithmetic mean 3.55 belongs to the set interval $(-2.03,9.13)$, which additionally confirms the acceptance of main hypothesis (H0). When we consider the two-tailed critical t-value, the same applies for supporting hypotheses (H1) and (H2), and we therefore accept both.

If we consider the one-tailed critical value of t-test for the risk level of $95 \%$ and 15 degrees of freedom, we can see that it equals 1.753 . We can claim with certainty that the arithmetic mean of the set main hypothesis $\mathrm{H} 0$ is greater than the lower limit, i.e. higher than 2.55. We can prove it if we, using the calculated data from Table 9A, calculate the corresponding t-value, which amounts to: $\bar{X}-1,753 \circ \frac{s}{\sqrt{15}}=2,549 \prec 3,55$ The same applies to supporting hypothesis H1 and $\mathrm{H} 2$.

Results of the conducted research reveal that one of the key problems of the process of bank mergers and acquisitions in $\mathrm{FB} \& \mathrm{H}$ is a lack, discrepancy, outdatedness, and misunderstanding of the accompanying regulations by Banking Agency of $\mathrm{FB} \& \mathrm{H}$, as a competent institution for supervision and control over banks in FB\&H. The research has shown that areas which are not adequately covered by accompanying regulations include financial reporting, internal control and auditing, and prescribed procedures in bank mergers and acquisitions by Banking Agency of FB\&H.

The set claim that regulations pertaining to the process of bank mergers and acquisitions in $\mathrm{B} \& \mathrm{H}$ are not harmonized was confirmed by the fact that legal regulations pertaining to bank mergers and acquisitions in $\mathrm{F} \& \mathrm{H}$ are regulated through a few legal and sub-legal acts, which is the reason why the Baking Agency of FB\&H, Securities Commission of FB\&H and Tax Administration of FB\&H frequently have different views on given issues. The respondents indicated that Law on Companies of $\mathrm{B} \& \mathrm{H}$ is inaccurate in defining the matter of legal entities' mergers and acquisitions and that therefore participants in mergers and acquisitions act in different ways in practice. 
The claim that banking regulations are incomprehensible was confirmed by respondents, who believe that one of main deficiencies of regulations is that regulations on the protection of banking risks and preservation of capital are over-complicated and incomprehensible.

The claim that continuous education in the area of banking in $F B \& H$ is insufficient and inadequate is confirmed by the fact that the education organized in consultancies is mainly of general character and applicable to all legal entities. Most respondents claim that the main source of information is education of internal character, which they receive from their home banks. As a solution, we point out that it is necessary for the Banking Agency of FB\&H to organize additional education, related to the banking sector.

With respect to internal control pertaining to bank mergers and acquisitions process, out of the responses we obtained, $81.81 \%$ respondents believe that internal control pertaining to bank mergers and acquisitions process in $\mathrm{FB} \& \mathrm{H}$ is insufficient and inadequate, while $18.19 \%$ respondents claim opposite. The respondents point out that internal control is unclearly defined by law and acts by Banking Agency of FB\&H. There are frequent instances of confusion of concepts of internal control and internal audit. Consequently, there are no prerequisites for the impact of internal supervision on the merger and acquisition process.

Besides, the respondents confirmed our claim pertaining to external control of the merger and acquisition process, and confirmed, in their responses, the insufficiency and inadequacy of external control, and pointed out that external supervision is conducted only by the Banking Agency of $\mathrm{FB} \& \mathrm{H}$, while inspection organs are not sufficiently trained in this area.

The respondents also confirmed that banks that are merged or acquired do not disclose all the information for financial statement users. They also claimed that banks mostly disclose quantitative information, while qualitative disclosures required by IFRS are not presented at all.

Regulations in FB\&H pertaining to the accounting aspect of bank mergers and acquisitions are not harmonized to the regulations in the European Union, which was confirmed by the research. These discrepancies primarily pertain to the IAS/IFRS and regulations applied on the territory of FB\&H and are related to the processes of bank mergers and acquisitions in $\mathrm{FB} \& \mathrm{H}$. Another discrepancy between FB\&H regulations and those in the EU related to the bank merger and acquisition process is that the EU member-states have adopted regulations of the bank merger and acquisition process, which regulate supervision and control of these processes. Besides, each merger or acquisition has the adopted plan of steps that are necessary to be made in the course of these processes. The control of the processes of bank mergers and acquisitions 
in $\mathrm{FB} \& \mathrm{H}$ is conducted by the Banking Agency of FB\&H, without including state and inspection authorities.

The research has confirmed that there is an obvious discrepancy between banks' financial reporting and IFRS/IAS requirements. The discrepancy derives from the fact that regulations by Banking Agency of FB\&H are not conformed to the application of IAS/IFRS, so that the Banking Agency of FB\&H does not require banks to disclose all the information required by IAS/IFRS. With respect to the banking sector and bank merger and acquisition processes, the discrepancy is, above all, viewed through IFRS 3 and IAS 39. Besides, Banking Agency has not prescribed a detailed plan, methodology and instructions related to bank mergers and acquisitions. It proves that users do not have a realistic, comprehensible and objective financial statement before and after bank merger and acquisition.

\section{Conclusions}

Starting from the basic goal of our research, which pertains to defined problems related to the accounting aspect of bank mergers and acquisitions in the Federation of $\mathrm{B} \& \mathrm{H}$, we believe that we have managed to prove the set hypotheses. The confirmed hypotheses proved that there is the insufficiency, discrepancy, lack of updating and misunderstanding of regulations pertaining to the accounting aspect of bank mergers and acquisitions in FB\&H. The insufficiency above all pertains to the regulations by the Banking Agency of $\mathrm{FB} \& \mathrm{H}$, as a competent institution for supervision over banks, which does not have the prescribed plan of steps that are necessary to be made in case of the status change of bank merger and acquisition. Legal regulations pertaining to the accounting aspect of mergers and acquisitions in $\mathrm{FB} \& \mathrm{H}$ are regulated in a few legal and sub-legal acts, which frequently leads to problems related to different interpretation of individual law articles by different institutions (Banking Agency of FB\&H, Tax Administration of FB\&H and Securities Commission of FB\&H). That regulations are not updated is confirmed by the fact that the Federation of $\mathrm{B} \& \mathrm{H}$ is late in applying IFRS / IAS and Basel regulations compared to countries in the region and the European Union member-states. As was confirmed in the research, these are complex legal regulations, which very often leads to misunderstanding of individual regulations. It, above all, pertains both to IFRS/IAS and to methodologies for managing individual risks banks are exposed to. Besides, the comparison between disclosures made by FB\&H banks who underwent status changes of merger or acquisition and mandatory disclosures, we proved that banks do not disclose all the information required by IFRS 3 - Business combinations, as mandatory disclosures in case of the occurrence of the described status changes. 
The research also confirmed our hypothesis that accounting regulations pertaining to the accounting aspect of bank mergers and acquisitions that are applied in FB\&H are not conformed to the European Union regulations pertaining to the same issues. We viewed the discrepancy with respect to IAS/IFRS, with a special review of standards dealing with accounting issues of the processes and IAS/IFRS, the application of which is specific for the banking sector. The paper also noted that the European Union state-members have adopted the regulation of bank merger and acquisition processes that deal with the supervision and monitoring if banks, which include state organs, while the supervision and monitoring over FB\&H banks, in case of mergers and acquisitions are conducted only by the Banking Agency of $\mathrm{FB} \& \mathrm{H}$, without including inspection organs.

Based on the conducted research and problems present in practice in case of bank mergers and acquisitions in FB\&H, we present the following guidelines for a possible solution to the described problems:

1. Prescribe the methodology and instructions for the bank merger and acquisition process in $\mathrm{FB} \& \mathrm{H}$

2. Strengthen supervision over the bank merger and acquisition processes in $\mathrm{FB} \& \mathrm{H}$

3. Conform the regulations of Banking Agency of FB\&H to the European Union regulations

4. Conform the disclosures by FB\&H banks to disclosure according to IFRS

5. Provide education for professional assets and liabilities assessors in case of bank mergers and acquisitions in $\mathrm{FB} \& \mathrm{H}$

6. Improve education in the area of banking

7. Pass a unique law dealing with the issue of bank mergers and acquisitions in $\mathrm{FB} \& \mathrm{H}$.

\section{References}

Agencija za bankarstvo FBiH, Informacija o bankarskom sistemu FBiH, Publikacije Retrieved from http:/ /www.fba.ba/index.php?page $=37$

Gulin, Danimir. Računovodstvo poslovnih kombinacija. Zagreb: RIF 3/96 HZRFD, 1996.

Jahić, Mehmed. Finansijsko računovodstvo: MSFI - MRS - PDV. Sarajevo: Udruženje revizora $\mathrm{FBiH}, 2008$.

Jakovčević, Drago. Bankovni potencijali, poslovna spajanja banaka i razvitak hrvatskog bankarstva. Ekonomski pregled, 52 (11-12) 1283-1302 (2001). 
Sinanagić, Murat. Računovodstvo - teorija i metodologija. Tuzla: Ekonomski fakultet u Tuzli, 1995.

Somun-Kapetanović, R. Statistika u ekonomiji i menadžmentu, Ekonomski fakultet, Sarajevo, (2008).

Zakon o bankama, Službene novine $\mathrm{FBiH}$, issues 39/98,32/00, 48/01, 27/02, 41/02, 58/02,13/03, 19/03 and 28/03.

Zelenika R. Metodologija i tehnologija izdrade naučnog i stručnog djela, četvrto izdanje. Rijeka: Ekonomski fakultet sveučilišta u Rijeci i Ekonomski fakultet Univerziteta u Ljubljani, 2000. 